J. Clin. Chem. Clin. Biochem.

Vol. 15,1977 , pp: $419-424$

\title{
Radioimmunological Measurement of 3,3'-Diiodothyronine in Serum and Amniotic Fluid
}

\author{
By H. Meinhold and P. Schürnbrand
}

Thyroid Research Group, Department of Nuclear Medicine and Endocrine Department, Klinikum Steglitz, Free University Berlin

(Received January 10/March 15, 1977)

Summary: A radioimmunoassay for the measurement of $3,3^{\prime}$-diiodo- $L$-thyronine $\left(\mathrm{rT}_{2}\right)$ in serum and amniotic fluid is described. Specific antisera to $\mathrm{rT}_{2}$ were produced by immunization of rabbits with $\mathrm{rT}_{2}$ conjugated to bovine serum albumin. The molar cross-reactivity tested for various iodothyronines and iodotyrosines was $0.3 \%$ for triiodothyronine and $0.001 \%$ for thyroxine. The sensitivity of the assay with a detection limit of $1.8 \mathrm{fmol} /$ tube $(0.94 \mathrm{pg} / \mathrm{tube})$ was due to the high avidity of the antiserum and the use of ${ }^{125} \mathrm{I}$-labelled $\mathrm{rT}_{2}$ of maximum specific radioactivity. In most of 45 normal subjects, serum $\mathrm{rT}_{2}$ levels measured in evaporated ethanol extracts were below the detection limit of $0.018 \mathrm{nmol} / \mathrm{l}$. Mean $\mathrm{rT}_{2}$ concentrations were $0.21 \mathrm{nmol} / 1$ in newborn cord serum and $0.10 \mathrm{nmol} / 1 \mathrm{in}$ amniotic fluid at 12 to 30 weeks of pregnancy. The molar concentration ratio of $3,3^{\prime}, 5^{\prime}$-triiodothyronine $\left(\mathrm{rT}_{3}\right)$ to $\mathrm{rT}_{2}$ was estimated to be 15.7 in cord serum of newborn. A similar $\mathrm{rT}_{3} / \mathrm{rT}_{2}$ ratio was found in adults after intravenous application of $500 \mu \mathrm{g} \mathrm{rT}_{3}$. Using these data and the known $\mathrm{rT}_{3}$ values, a hypothetical mean serum $\mathrm{rT}_{2}$ concentration in adult normal subjects of $0.015 \mathrm{nmol} / 1$ was calculated. The radioimmunoassay described may be a useful analytical tool in studies of the synthesis as well as the metabolism of thyroid hormones.

\section{Radioimmunologische Bestimmung von 3,3'-Dijodthyronin in Serum und Fruchtwasser}

Zusammenfassung: Es wird ein Radioimmunoassay zur Messung von 3,3'-Dijod- $L$-thyronin in Serum und Fruchtwasser beschrieben. Spezifische Antiseren gegen $\mathrm{rT}_{2}$ wurden durch Immunisierung von Kaninchen mit $\mathrm{rT}_{2}-\mathrm{Rinder-}$ serumalbumin-Konjugaten gewonnen. Die molare Kreuzreaktivität, die für verschiedene Jodthyronine und -tyrosine ermittelt wurde, betrug für Trijodthyronin 0,3\%, für Thyroxin 0,001\%. Die hohe Empfindlichkeit der Methode (Nachweisgrenze 1,8 fmol bzw. 0,94 pg pro Inkubationsprobe) beruht einerseits auf der hohen Avidität des verwendeten Antiserums, andererseits auf der Verwendung von ${ }^{125} \mathrm{~J}$-markiertem $\mathrm{rT}_{2}$ mit maximaler spezifischer Radioaktivität. Zur radioimmunologischen Bestimmung wurden eingedampfte Ethanolextrakte von Serum- oder FruchtwasserProben eíngesetżt. Die Konzentrationen von $\mathrm{rT}_{2}$ im Serum lagen in einem Kollektiv von 45 Normalpersonen zum überwiegenden Teil unter der Nachweisgrenze der Methode von $0,018 \mathrm{nmol} / \mathrm{l}$. In Seren aus Nabelschnurblut von Neugeborenen wurde ein mittlerer $\mathrm{rT}_{2}$-Spiegel von $0,21 \mathrm{nmol} / 1$ gemessen. In Fruchtwasser aus der 12 . bis 30 . Schwangerschaftswoche lag die mittlere $\mathrm{rT}_{2}=$ Konzentration bei $0,10 \mathrm{nmol} / 1$. Das molare Konzentrationsverhältnis von $3,3^{\prime}, 5^{\prime}$ Trijodthyronin $\left(\mathrm{rT}_{3}\right)$ zu r $\mathrm{T}_{2}$ betrug im Serum von Nabelschnurblut Neugeborener 15,7. Ein ähnliches $\mathrm{rT}_{3} / \mathrm{rT}_{2}$-Verhältnis wurde im Serum Erwachsener nach intravenöser Applikation von $500 \mu \mathrm{g} \mathrm{IT}_{3}$ gefunden. Unter Benutzung dieser Daten und der bekannnten $\mathrm{rT}_{3}$-Werte ließß sịch für erwachsene Normalpersonen eine hypothetische mittlere $\mathrm{rT}_{2}$ Serumkonzentration von $0,015 \mathrm{nmol} / \mathrm{l}$ berechnen. Die beschriebene Methode dürfte sich als nützlich für Untersuchungen sowohl der Synthese wie auch des Metabolismus von Schilddrüsenhormonen erweisen.

\section{Introduction}

The availability of radioimmunological methods for the routine estimation of the thyroid hormones, triiodothyronine $\left(T_{3}\right)^{1}$ and thyroxine $\left(T_{4}\right)$, and the recent

\footnotetext{
1) Abbreviations: $r T_{2}=3,3^{\prime}$-diiodo- $L$-thyronine; $T_{3}=3,5,3^{\prime}$ triiodo- $L$-thyronine; $r \mathrm{~T}_{3}=3,3^{\prime}, 5^{\prime}=$ triiodo $-L$-thyronine; $\mathrm{T}_{4}=L$-thyroxine.
}

development of sensitive radioimmunoassays for $3,3^{\prime}, 5^{\prime}$ triiodothyronine (reverse $\left.T_{3}, \mathrm{rT}_{3}\right)(1,2)$ have resulted in an intensification of studies on the peripheral conversion of $\mathrm{T}_{4}$ by monodeiodination. From these studies a series of quantitative data on the conversion rates of $T_{4}$ to $T_{3}$ $(3,4)$ and more recently on the peripheral generation of 
$\mathrm{rT}_{3}$ from $\mathrm{T}_{4}(5,6)$ have become available. These kinetic studies as well as recent investigations regarding the thyroidal formation of iodothyronines (7) have stimulated interest in analytical methods for the quantitative determination of a further deiodination product of $T_{4}$, i. e. $3,3^{\prime}$-diiodothyronine $\left(\mathrm{rT}_{2}\right)$.

This paper describes the methodology of a radioimmunoassay for $\mathrm{rT}_{2}$ as well as its application for $\mathrm{rT}_{2}$ determinations in serum and amniotic fluid. Preliminary results have been reported elsewhere (8). In the course of the development of this method, two papers as abstracts were published regarding a $\mathrm{rT}_{2}$ radioimmunoassay. Chopra et al. (9) applied a $\mathrm{rT}_{2}$ radioimmunoassay to the measurement of the in-vitro deiodination of $\mathrm{T}_{3}$ and $\mathrm{rT}_{3}$ added to liver homogenates. Earl et al. (10) investigated the extrathyroidal formation of $\mathrm{rT}_{2}$ in athyreotic patients receiving high doses of $T_{4}$ over a long period. At present no quantitative data are available concerning the natural existence of $\mathrm{rT}_{2}$ in man.

\section{Materials and Methods}

\section{Antisera}

Antisera to $\mathrm{rT}_{2}$ were produced in three rabbits immunized by serial injections of a conjugate of $\mathrm{rT}_{2}$ to bovine serum albumin in complete Freund's adjuvant as described earlier for raising antibodies to $T_{3}$ and $T_{4}(11,12)$. All immunized rabbits produced antisera satisfactory for radioimmunoassay of $\mathrm{rT}_{2}$. The antiserum selected for use in the studies to be described was obtained after three injections of the immunogen, eight weeks after starting immunization. It was used in a final dilution of 1:180 000 in an incubation volume of $600 \mu \mathrm{l}$.

The $\mathrm{rT}_{2}$ conjugate to bovine serum albumin, all iodothyronines and iodotyrosines used in this study were obtained by courtesy of Henning Berlin GmbH.

Preparation of ${ }^{125} \mathrm{I}_{\text {-labelled }} \mathrm{rT}_{2}$

Labelled $\mathrm{rT}_{2}$ of maximum specific radioactivity was obtained by radioiodination of 3-iodo- $L$-thyronine with chloramin $T$. 3-iodo- $L$-thyronine was dissolved in $0.01 \mathrm{~mol} / 1$ sodium hydroxide, chloramin T (Merçk, Darmstadt) and sodium disulfite in $0.1 \mathrm{~mol} / \mathrm{l}$ phosphate buffer $\mathrm{pH} 7,0$. For labelling, $10 \mu \mathrm{l}$ volumina of the following reagents were pipetted into a microflex vial (Radiochemical Centre, Amersham) containing $40 \mu 10.5 \mathrm{~mol} / 1$ phosphate buffer $\mathrm{pH} 7.5: 37 \mathrm{MBq}(1 \mathrm{mCi})^{125}$ Iodine (approximately $0.5 \mathrm{nmol}$ iodine, Radiochemical Centre, Amersham), 2 nmol 3-iodo- $L$-thyronine, $0.2 \mu \mathrm{mol}$ chloramin $\mathrm{T}$. After an incubation period of $30 \mathrm{~s}, 1.5 \mu \mathrm{mol}$ sodium disulfite were added. The reaction mixture was transferred to a paper strip (What man $3 \mathrm{MM} ; 3 \mathrm{~cm} \times 56 \mathrm{~cm}$ ) and the labelled reaction products were separated by descending preparative paper chromatography using iso-amylalcohol: $\mathrm{n}$-hexane: $2 \mathrm{~mol} / 1$ ammonia (volumes, $50 \mathrm{ml}+10 \mathrm{ml}+60 \mathrm{ml}$ ) as elution system (13). The radioactivity distribution along the paper strip was estimated using a paper and thin-layer scanner (Dünnschichtscanner II, Berthold, Wildbad). The paper segment corresponding to the ${ }_{125} \mathrm{~S}_{-} \mathrm{T}_{2}$ peak was cut out and the labelled compound was eluted with methanol containing $0.25 \%$ concentrated ammonia. This solution was stored at $-20^{\circ} \mathrm{C}$. The radiochemical purity was tested by thin-layer chromatography (silica gel $60 \mathrm{~F}_{254}$ plates, Merck) in ethyl acetate:methanol: $3 \mathrm{~mol} / \mathrm{l}$ ammonia (volumes, $50 \mathrm{ml}+20 \mathrm{ml}+10 \mathrm{ml}$ ). For use in the assay, the methanol-ammonia eluate of labelled $\mathrm{rT}_{2}$ was directly diluted with barbital buffer.

\section{Preparation of test samples}

Serum and amniotic fluid samples were extracted with two parts of ethanol. $300 \mu$ l ethanol extract, which were equivalent to $100 \mu \mathrm{l}$ of original sample, were evaporated to dryness and used for $\mathrm{rT}_{2}$ assay. The extraction yields were estimated to be $\mathbf{9 8 . 5} \%$ for serum and $100 \%$ for amniotic fluid. For recovery experiments, known amounts of unlabelled $\mathrm{rT}_{2}$ were addded to serum, which was then extracted in the routine way. Enrichment of iodothyronines from serum was performed using anion-xchange resins (standard II columns, Bio-Rad, München). The columns were equilibrated with $3 \mathrm{ml} 0.2 \mathrm{~mol} / \mathrm{l}$ sodium hydroxide. $5 \mathrm{ml}$ serum was hydrolysed with $5 \mathrm{ml} 0.2 \mathrm{~mol} / \mathrm{l}$ sodium hydroxide for $15 \mathrm{~min}$ and passed through the columns. The columns were then washed two times with $5 \mathrm{ml}$ of a solution of isopropanol and sodium acetate (Bio-Rad), two times with $2.5 \mathrm{~mol} / \mathrm{l}$ acetic acid and once with $0.5 \mathrm{ml}$ glacial acetic acid. The iodothyronines were eluted with $3 \mathrm{ml}$ of glacial acetic acid. The iodothyronine fraction was evaporated to dryness by an air stream and the residue redissolved in $1 \mathrm{ml}$ barbital buffer. In this solution, tracer experiments yielded a mean recovery of $64 \%$ of added labelled $\mathrm{rT}_{2} .200 \mu \mathrm{l}$ samples, which were equivalent to $1 \mathrm{ml}$ of original serum, were pipetted for $\mathrm{rT}_{2}$ assay. $\mathrm{rT}_{2}$-free serum samples prepared by charcoal extraction were run in each set of enrichment experiments to correct for blank effects.

\section{Assay procedure}

The $\mathrm{rT}_{2}$ assay was performed in $0.08 \mathrm{~mol} / \mathrm{l}$ barbital buffer $\mathrm{pH} 8.6$ containing $2 \mathrm{~g} / \mathrm{l}$ bovine serum albumin and $200 \mathrm{mg} / 1$ sodium azide. Reagents were incubated as follows: Evaporated serum or amniotic fluid extract (representing $100 \mu$ of original sample), or $100 \mu \mathrm{l}$ standard solution (from 1.8 to $914 \mathrm{fmol}$, i. e. 0.94 to $480 \mathrm{pg} \mathrm{IT}$ ), $100 \mu \mathrm{l}$ tracer solution (containing $925 \mathrm{~Bq}(25 \mathrm{nCi}$ ) corresponding to approximately $6 \mathrm{pg}{ }^{125} \mathrm{I}-\mathrm{rT}_{2}$ and $0.5 \mu \mathrm{l}$ normal rabbit serum), $100 \mu$ antiserum to $\mathrm{rT}_{2}$ diluted 1:30000, and barbital buffer to give a final volume of $600 \mu \mathrm{l}$. After an incubation period of 1 to 3 hours at room temperature, $100 \mu$ lantirabbit gammaglobulin serum (donkey) were added and incubated at $4{ }^{\circ} \mathrm{C}$ over night. After centrifugation, the precipitated radioactivity was measured. Corrections were made for non-specific binding which was usually between 1.5 and $2.5 \%$ of total activity. All measurements were performed in triplicate.

$\mathrm{rT}_{3}$ measurements in serum and amniotic fluid were performed by a modification of our $\mathrm{rT}_{3}$ radioimmunoassay published previously (2). $\mathrm{rT}_{3}$ was directly estimated in $50 \mu 1$ samples of serum or amniotic fluid after inhibition of serum binding proteins with $150 \mu \mathrm{g} /$ tube and $100 \mu \mathrm{g} /$ tube 8-anilino-1-naphthalene sulfonic acid in the case of serum and amniotic fluid, respectively. $T_{3}$ and $T_{4}$ were measured by radioimmunoassay as previously reported $(11,12)$.

\section{Results}

\section{Labelling}

The paper chromatogram (fig. 1) shows a clear separation of the two major labelled products: $\mathrm{rT}_{2}$ with radioactive iodine in $3^{\prime}$-position and double labelled $\mathrm{rT}_{3}$ with ${ }^{125}$ Iodine in $3^{\prime}$ - and $5^{\prime}$-position of the iodothyronine molecule. Free iodide migrates only a short distance in this system. The $\mathbf{R}_{\mathbf{f}}$-values of the separated compounds increase with the length of time the chromatographic system is in use and are therefore not listed. The radiochemical purity of carrier-free labelled $\mathrm{rT}_{2}$ was higher than $99.5 \%$ as tested by thin-layer chromatography (fig. 1 inset). The labelled compound when stored in methanol-ammonia solution at $-20^{\circ} \mathrm{C}$ could be used for some months without significant damage. Free iodine impurity did not exceed $4 \%$ three months after labelling. 


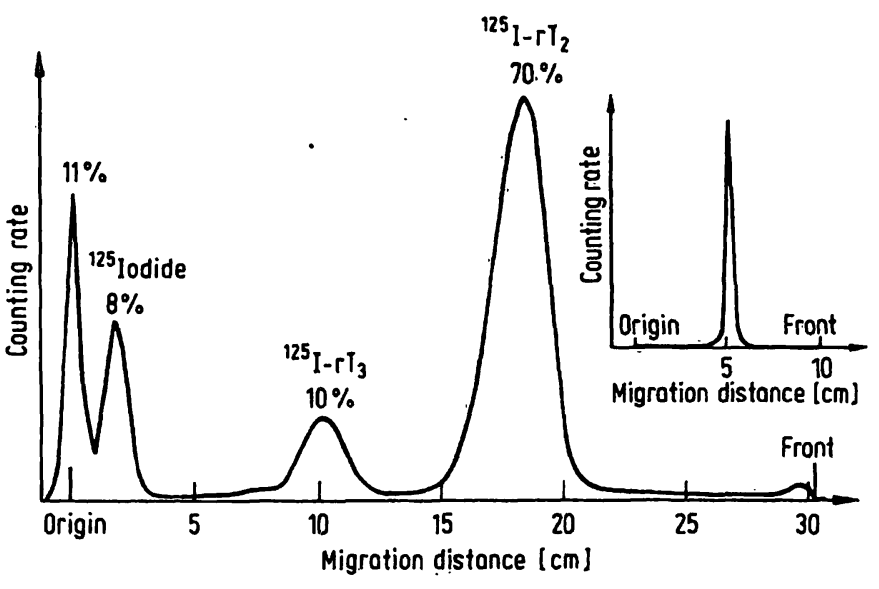

Fig. 1. Separation of the reaction mixture after radioiodination of 3-iodo-L-thyronine by preparative paper chromatography.

Inset: Thin-layer chromatogram of ${ }^{125} \mathrm{I}_{-} \mathrm{r}_{2}$ after elution from paper.

Tab. 1. Relative molar cross-reactivity of iodothyronines and iodotyrosines in the $\mathrm{rT}_{2}$ radioimmunoassay.

\begin{tabular}{lc}
\hline Compound & $\begin{array}{l}\text { Molar } \\
\text { cross-reactivity } \\
(\%)\end{array}$ \\
\hline 3,3'-diiodo- $L$-thyronine $\left(\mathrm{rT}_{2}\right)$ & 100 \\
3,5-diiodo- $L$-thyronine & 0.003 \\
3,5,3'-triiodo- $L$-thyronine $\left(\mathrm{T}_{3}\right)$ & 0.31 \\
3,3', & 0.042 \\
$L$-thiiodo- $L$-thyronine $\left(\mathrm{rT}_{3}\right)$ & 0.001 \\
3-iodo- $L$-tyrosine & $<0.001$ \\
3,5-diiodo- $L$-tyrosine & $<0.001$ \\
\hline
\end{tabular}

\section{Methodology}

Molar cross-reactivity values of the antiserum with various iodothyronines and iodotyrosines are presented in table 1 . The cross-reactivity was assessed by determining the molar amount of the analogue required to cause a $50 \%$ displacement of labelled $\mathrm{rT}_{2}$ originally bound. The highest cross-reactivity was observed for $\mathrm{T}_{3}(0.31 \%) . \mathrm{T}_{4}$ demonstrated the lowest cross-reactivity of the iodothyronines tested: $0.001 \%$ on a molar basis, less than $0.001 \%$ on a weight basis. The iodotyrosines showed absolutely no cross-reaction effect up to $1 \mathrm{nmol} /$ tube. $4 \mathrm{nmol} /$ tube monoiodotyrosine and diodotyrosine caused only a slight depression of $\hat{B} / B_{0}$ values: 95 and $98 \%$, respectively (fig. 2).

Scatchard plot analysis yielded an effective equilibrium constant (14) of $2 \times 10^{10} \mathrm{l} / \mathrm{mol}$. Due to this high avidity of the chosen antiserum, a highly sensitive $r \bar{T}_{2}$ radioimmunoassay could be established. The lower limit of detection was $1.8 \mathrm{fmol} /$ tube $(0.94 \mathrm{pg} /$ tube $)$. A $50 \%$ inhibition of labelled $\mathrm{rT}_{2}$ bound to antibody was achieved with 85 to $95 \mathrm{fmol} /$ tube $\mathrm{rT}_{2}$ (45 to $50 \mathrm{pg} /$ tube) in five successive assays.

The mean recovery of unläbelled $\mathrm{rT}_{2}$ added to a normal serum pool in amounts ranging from 0.036 to $4.60 \mathrm{nmol} / \mathrm{I}$ serum was $103 \%$ (range 92 to $112 \%$ ). Intra-assay reproducibility was evaluated by 18 fold determination of serum from a normal volunteer having received exogenous $\mathrm{rT}_{2}$ for kinetic studies and was found to be $38.8 \pm 3.0$ $\mathrm{fmol} /$ tube (coefficient of variation $7.8 \%$ ). The mean inter-assay reproducibility of 6 samples in 5 successive assays (mean $\mathrm{rT}_{2}$ between 56 und $148 \mathrm{fmol} /$ tube) was $8.8 \%$ ranging from 5.6 to $14.5 \%$.

\section{Application to measurements in serum and} amniotic fluid

The radioimmunoassay was applied to $\mathrm{rT}_{2}$ measurements in serum and amniotic fluid. Table 2 presents mean values and ranges of these estimates in serum of normal subjects, in arterial cord serum of newborn infants, and in amniotic fluid at early pregnancy stages. $\mathrm{rT}_{3}$ values are also shown. Serum $\mathrm{rT}_{2}$ measured in 45 normal subjects in three different assays was below the detection limit of $0.018 \mathrm{nmol} / 1$ in approximately $80 \%$ of the collective. The upper range in sera with measurable $\mathrm{rT}_{2}$ concentrations was $0.086 \mathrm{nmol} / \mathrm{l}(0.045$ $\mu \mathrm{g} / \mathrm{l})$. In biological fluids with high $\mathrm{rT}_{3}$ levels clearly measurable $\mathrm{rT}_{2}$ concentrations were found. The mean $\mathrm{rT}_{2}$ value in 39 newborn cord sera was $0.211 \mathrm{nmol} / \mathrm{l}$ $(0.11 \mu \mathrm{g} / 1)$. The mean $\mathrm{rT}_{3}$ concentration of these samples $(3.13 \mathrm{nmol} / 1)$ is approximately ten times higher than in serum of adult normal subjects. The mean $\mathrm{rT}_{2}$ level in amniotic fluids at 12 to 30 weeks of pregnancy was found to be $0.100 \mathrm{nmol} / \mathrm{l}(0.053 \mu \mathrm{g} / \mathrm{l})$. The mean $\mathrm{rT}_{3}$ level in amniotic fluid of $3.21 \mathrm{nmol} / 1$ is comparable with that in cord serum. $T_{3}$ and $T_{4}$ concentrations in amniotic fluid are very low (data not shown).

The mean value of molar $\mathrm{rT}_{3} / \mathrm{rT}_{2}$ ratios in cord serum was calculated to be 15.7. The mean $\mathrm{rT}_{3} / \mathrm{rT}_{2}$ ratio in amniotic fluid was 38.1 with single values showing a wide distribution between 3.0 and 86 .

After tenfold enrichment of iodothyronines by anionexchange resins, we have found a mean $\mathrm{rT}_{2}$ concentration of $0.074 \mathrm{nmol} / 1(0.039 \mu \mathrm{g} / \mathrm{l})$ in five normal sera. $\mathrm{rT}_{2}$ determination in the same nonenriched sera yielded $\mathrm{rT}_{2}$ values slightly above the detection limit of 0.018 nmol/1. For control experiments, known amounts of unlabelled $\mathrm{r} \bar{T}_{2}$ were added to $\mathrm{rT}_{2}$-free serum and normal serum prior to enrichment. The recovery of $\mathrm{rT}_{2}$ in these samples after enrichment was between 88 and $104 \%$.

Preliminary results regarding the kinetics of $\mathrm{rT}_{2}$ in man were obtained by the measurement of serum $\mathrm{rT}_{2}$ after a bulk injection of $950 \mathrm{nmol}(500 \mu \mathrm{g}) \mathrm{rT}_{2}$ intravenously. The curve in figure 3 demonstrates the disappearance of immunoassayable $\mathrm{rT}_{2}$ from serum in one normal volunteer. A rapid rate of $\mathrm{rT}_{2}$ elimination from serum within the first hour is followed by a constant disappearance rate up to 6 hours after injection. During this period $\mathrm{rT}_{2}$ concentration in serum decreased to approximately $.0 .1 \%$ of the value measured $5 \mathrm{~min}$ after injection. From 
Tab. 2. Concentrations of $\mathrm{rT}_{2}$ and $\mathrm{rT}_{3}$ in serum and amniotic fluid. Range $=$ extreme values.

\begin{tabular}{|c|c|c|c|c|c|}
\hline & Number & & $\begin{array}{l}\mathrm{rT}_{2} \\
(\mathrm{nmol} / \mathrm{l})\end{array}$ & $\begin{array}{l}\mathrm{rT}_{3} \\
(\mathrm{nmol} / \mathrm{l})\end{array}$ & $\begin{array}{l}\mathrm{rT}_{3} / \mathrm{rT}_{2} \\
\text { ratio }\end{array}$ \\
\hline Normal subjects (serum) & 45 & $\begin{array}{l}\text { Mean } \pm \text { SD } \\
\text { Range }\end{array}$ & $\begin{array}{l}<0.018 \\
<0.018-0.086\end{array}$ & $\begin{array}{l}0.31 \pm 0.14 \\
0.06-0.63\end{array}$ & $\overline{-}$ \\
\hline Newborn (cord serum) & 39 & $\begin{array}{l}\text { Mean } \pm \text { SD } \\
\text { Range }\end{array}$ & $\begin{array}{l}0.211 \pm 0.062 \\
0.095-0.324\end{array}$ & $\begin{array}{l}3.13 \pm 0.78 \\
1.66-4.90\end{array}$ & $\begin{array}{r}15.7 \pm 4.9 \\
8.9-29.8\end{array}$ \\
\hline $\begin{array}{l}\text { Amniotic fluid at } 12 \text { to } \\
30 \text { weeks of pregnancy }\end{array}$ & 26 & $\begin{array}{l}\text { Mean } \pm \text { SD } \\
\text { Range }\end{array}$ & $\begin{array}{l}0.100 \pm 0.052 \\
0.051-0.276\end{array}$ & $\begin{array}{l}3.21 \pm 1.36 \\
0.92-5.96\end{array}$ & $\begin{array}{r}38.1 \pm 19.6 \\
3.0-86.4\end{array}$ \\
\hline
\end{tabular}

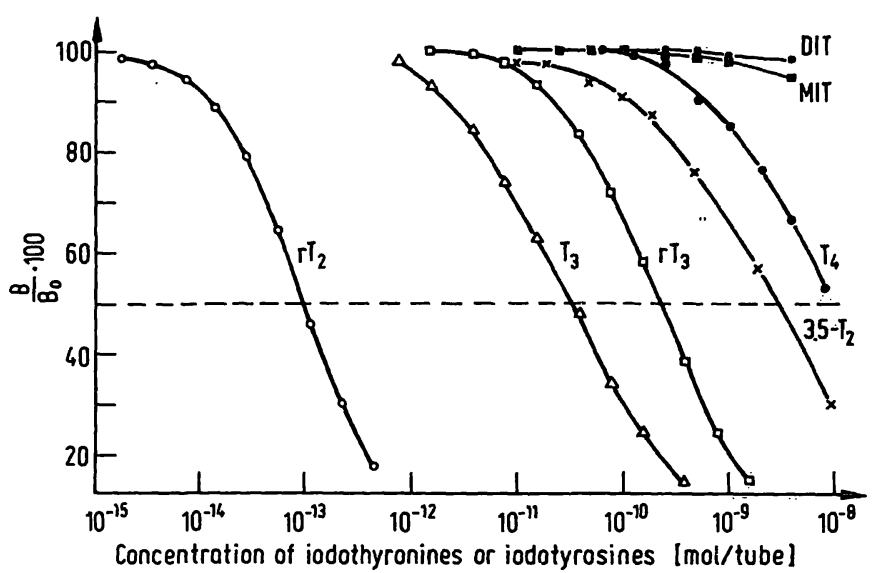

Fig. 2. Dose-response curves showing inhibition of binding of ${ }_{125} \mathrm{~S}_{\mathrm{I}} \mathrm{r} \mathrm{T}_{2}$ by unlabelled iodothyronines and iodotyrosines (MIT $=3$-iodo- $L$-tyrosine, DIT $=3,5$-diiodo- $L$-tyrosine $)$.

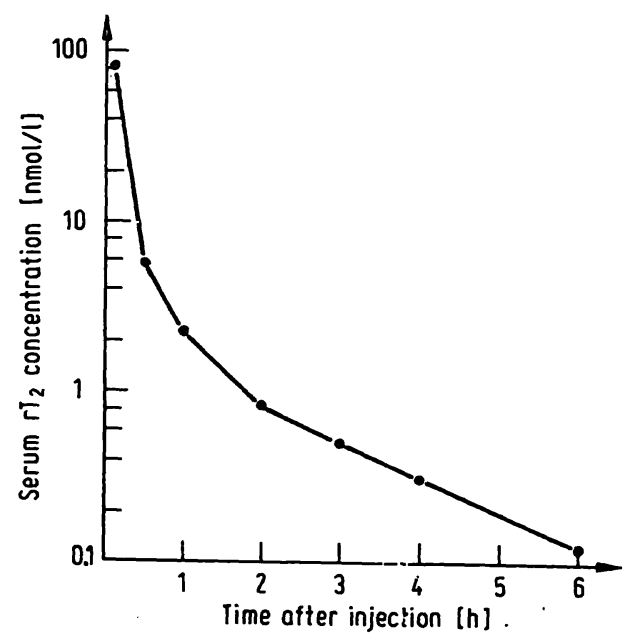

Fig. 3. Disappearance of immunoassayable $\mathrm{rT}_{2}$ from serum of one normal volunteer after intravenous application of $500 \mu \mathrm{g} \mathrm{rT}$.

the linear part of the elimination curve, the halftime of $\mathrm{rT}_{2}$ in serum was estimated to be 1.2 hours in that person. In a further experiment 770 ' $\mathrm{nmol}(500 \mu \mathrm{g}) \mathrm{rT}_{3}$ were injected in to three normal volunteers. Serum concentrations of $\mathrm{rT}_{3}$ as well as that of $\mathrm{rT}_{2}$ generated from $\mathrm{rT}_{3}$ by peripheral deiodination were then measured by radiöimmunoassay. Figure 4 shows $\mathrm{rT}_{3}$ and $\mathrm{rT}_{2}$ serurn concen-

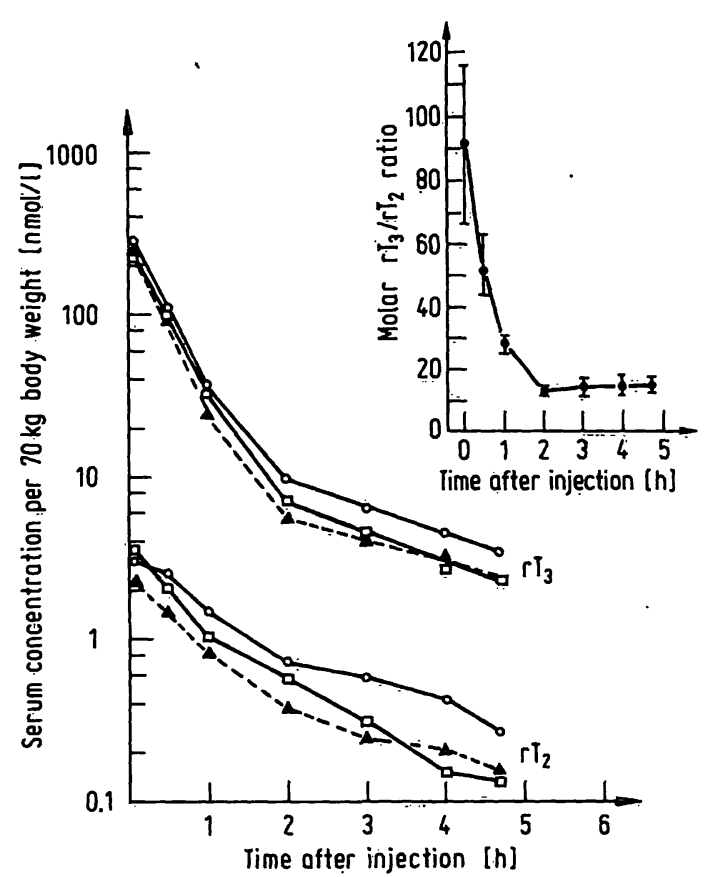

Fig. 4. Disappearance of $\mathrm{rT}_{3}$ and $\mathrm{rT} \mathrm{T}_{2}$ from serum of three normal volunteers after intravenous application of $500 \mu \mathrm{g} \mathrm{rT}$. The inset shows the mean values of $\mathrm{rT}_{3} / \mathrm{rT}_{2}$ ratios. The ranges about each medium point indicate the upper and lower value of measurements taken on the three subjects.

trations after normalization to $70 \mathrm{~kg}$ body weight within 5 hours post $\mathrm{rT}_{3}$ injection. The inset presents mean $\mathrm{rT}_{3} / \mathrm{rT}_{2}$ ratios determined from the elimination curves. These ratios decrease rapidly from 92 to approximately 14 within 2 hours, then remain constant during the next 3 hours. The mean \pm standard deviation of all single $\mathrm{rT}_{3} / \mathrm{rT}_{2}$ ratios between 2 and 5 hours after injection was calculated to be $14.3 \pm 2.2$.

\section{Discussion}

The presence of $\mathrm{rT}_{2}$ in thyroid tissue and plasma of rats was first reported by Roche et al. (15) in 1955. The method used in these early studies was based on the paper chromatographic separation of in-vivo labelled iodothyronines after intravenous administration of ${ }^{131}$ Iodide in rats. Through the application of this techni- 
que it was found, that the relative $\mathrm{rT}_{2}$ concentration in plasma was approximately $25 \%$ of that of thyroxine. $\mathrm{T}_{3}$ and $\mathrm{rT}_{3}$ were detected in much lower concentrations. Although the existence of $\mathrm{rT}_{2}$ in the thyroid gland of the rat could be confirmed (7), it appears that the reported value of the relative $\mathrm{rT}_{2}$ concentration in rat plasma is erroneously high. This is probably due to artefacts in the two-dimensional paper chromatography. From kinetic studies with radioactive labelled $\mathrm{rT}_{2}$ in man it was concluded that due to its extremely short biological halftime the presence of $\mathrm{rT}_{2}$ in human serum would be very improbable (16). As a result of these early studies it is evident that a direct quantitative determination of $\mathrm{rT}_{2}$ in biological fluids is only possible by the use of a highly specific and highly sensitive analytical method. The radioimmunoassay for $\mathrm{rT}_{2}$ described in this paper satisfies these criteria.

By the immunization of three rabbits with $\mathrm{rT}_{2}$ conjugated to bovine serum albumin, antisera with high concentrations of antibodies to $\mathrm{rT}_{2}$ were obtained in two animals, allowing final assay dilutions of 1:120000 and 1:180 000, respectively. These high titres are comparable with that of antisera to $T_{3}$ obtained previously using the same immunization procedures (11), whereas immunizations with $\mathrm{T}_{4}(12)$ and $\mathrm{rT}_{3}(2)$ conjugates to bovine serum albumin yielded antisera with titres tenfold lower. It seems likely that these differences in the immune response may be due to the presence of only one iodine atom in $3^{\prime}$-position in the case of $\mathrm{rT}_{2}$ and $\mathrm{T}_{3}$, and the presence of two iodines at the outer phenolic ring in the $T_{4}$ and $\mathrm{rT}_{3}$ molecule.

The highest cross-reactivity of the antiserum used for $\mathrm{rT}_{2}$ assay was observed for $\mathrm{T}_{3}(0.31 \%)$ reflecting again the above mentioned similarities between $\mathrm{rT}_{2}$ and $\mathrm{T}_{3}$ with respect to chemical structure. A very low crossreactivity was found for $\mathrm{T}_{4}(0.001 \%)$, which of all iodothyronine components in biological material is generally present in the highest concentration. Due to this low cross-reactivity the measurement of $\mathrm{rT}_{2}$ in serum is not influenced by $\mathrm{T}_{4}$. In the same manner, the absence of cross-reactions with monoiodotyrosine and diiodotyrosine exclude any interference of $\mathrm{rT}_{2}$ measurements in thyroid tissue by these compounds.

The high sensitivity of this $\mathrm{r} \mathrm{T}_{2}$ radioimmunoassay is a consequence of the high avidity of the antiserum and the use of labelled $\mathrm{rT}_{2}$ with maximum specific radioactivity. We have found a twofold effective equilibrium constant of $\mathrm{rT}_{2}$ antiserum in comparison to our $\mathrm{rT}_{3}$ radioimmunoassay (2). The lower limit of detection and the $50 \%$ intercept are approximately half of that obtained in the $\mathrm{rT}_{3}$ assay.

The finding that $r \mathrm{~T}_{2}$ measured by our method in unconcentrated serum samples was undetectable in most of normal subjects, confirm the earlier speculations of Stanbury \& Morris (16) that serum $\mathrm{rT}_{2}$ levels in man should be extremely low. In cord serum, however, clear- ly increased $\mathrm{rT}_{2}$ levels with a mean value of $0.211 \mathrm{nmol} / \mathrm{l}$ were found. Elevated $\mathrm{rT}_{2}$ concentrations (mean 0.100 $\mathrm{nmol} / \mathrm{l}$ ) compared to serum levels of adult normal subjects were also observed in amniotic fluid at early pregancy stages. In both cord serum and amniotic fluid, extremely high $\mathrm{rT}_{3}$ concentrations accompanied by reduced $\mathrm{T}_{3}$ levels have been recently reported $(17,18,19)$.

The mean molar $\mathrm{rT}_{3} / \mathrm{rT}_{2}$ ratio in cord serum was found to be 15.7. A similar ratio of 14.3 was observed in three normal volunteers 2 to 5 hours after application of 500 $\mu \mathrm{g} \mathrm{rT}$. In this experiment the $\mathrm{rT}_{3} / \mathrm{rT}_{2}$ ratio decreased rapidly in the first 2 hours. This ratio remained constant after the $\mathrm{rT}_{3}$ elimination curve showed a linear decrease, indicating the equilibration of $\mathrm{rT}_{3}$ in its total distribution space. The comparability of the $\mathrm{rT}_{3} / \mathrm{rT}_{2}$ ratio found in the kinetic experiment with that in cord serum suggest that the peripheral deiodination rate of $\mathrm{rT}_{3}$ as well as the degradation rate of $\mathrm{rT}_{2}$ are similar in normal persons and newborn infants. This conclusion enables the calculation of a hypothetical mean $\mathrm{rT}_{2}$ concentration in normal subjects. Using the mean $\mathrm{rT}_{3}$ concentration of 0.31 $\mathrm{nmol} / \mathrm{l}$ measured in our normal collective and a $\mathrm{rT}_{3} / \mathrm{rT}_{2}$ ratio of about 15 , one may calculate that the mean $\mathrm{rT}_{2}$ level in serum of normal adults should be approximately $0.015 \mathrm{nmol} / \mathrm{l}$, a value slightly below our detection limit.

On the other hand, a mean $\mathrm{rT}_{2}$ value of $0.074 \mathrm{nmol} / 1$ was measured in a limited number of normal sera after iodothyronine enrichment. Several factors may be responsible for this discrepancy. The accuracy of measurements near the detection limit of a radioimmunoassay is more or less influenced by protein interferences of individual test sera, by the quality of antigen-free serum and by other factors, even when ethanolic serum extracts were assayed. In the case of $\mathrm{rT}_{2}$ enriched test samples, it cannot be excluded that artefacts due to anion-exchange chromatography contribute to systematically elevated results. At present, it is therefore not possible to specify a reliable mean serum $\mathrm{rT}_{2}$ level in adult normal subjects. From our results, however, it seems likely that this value should be lower than $0.1 \mathrm{nmol} / \mathrm{l}$.

It is at the present time not clear whether $\mathrm{rT}_{2}$ has any physiological relevance. Therefore the usefulness of the described method in clinical diagnostics is questionable. However, the possibility for the quantitative determination of $\mathrm{rT}_{2}$ may be of importance for the further clarification of peripheral thyroxine deiodination, especially in kinetic and in vitro experiments.

\section{Acknowledgements}

We are indebted to Dr. J. W. Dudenhausen, Unit of Perinatal Medicine, Free University Berlin, for kindly providing amniotic fluids. We are grateful to $J$. Franke for help in immunization of rabbits, and to $C$. H. Kim for excellent technical assistance. This work was supported by the Deutsche Forschungsgemeinschaft (Me 582/1). 


\section{Addendum}

After completion of this paper, a publication of $W u$ et al. regarding a radioimmunoassay for the measurement of $\mathrm{rT}_{2}$ in serum and amniotic fluid was brought to our attention (Wu, S. Y., Chopra, I. J., Nakamura, Y., Solomon, D. H. \& Bennett, L. R. (1976), J. Cliñ. Endocrinol. Metab. 43, 682-685).

\section{References}

1. Chopra, I. J. (1974), J. Clin. Invest. 54, 583-592.

2. Meinhold, H., Wenzel, K. W. \& Schürnbrand, P. (1975), this J. 13, 571-574.

3. Surks, M. I., Schadlow, A. R., Stock, J. M. \& Oppenheimer, J. H. (1973), J. Clin. Invest. 52, 805-811.

4. Inada, M., Kasagi, K., Schunichiro, K., Kazama, Y., Takayama, H., Torizuka, K., Fukase, M. \& Soma, T. (1975), J. Clin. Invest. 55, 1337-1348.

5. Chopra, I. J. (1976), J. Clin. Invest. 58, 32-40.

6. Meinhold, H., Wenzel, K. W. \& Schürnbrand, P. (1976), 5 th International Congress of Endocrinology, Hamburg, Abstract 123.

7. Taurog, A., Riesco, G. \& Larsen, P. R. (1976), Endocrinology 99, 281-290.

8. Meinhold, H. \& Schürnbrand, P. (1977), Acta Endoç inol. (Copenhagen) Suppl. 208, 116-117.

9. Chopra, I. J., Wu, S. Y. \& Solomon, D. H. (1976), 5 th International Congress of Endocrinology, Hamburg, Abstract 120.

10. Earll, J. M., Burman, K. D. \& Wartofsky, L. (1976), 5 th International Congress of Endocrinology, Hamburg, Abstract 122.
11. Meinhold, H. \& Wenzel, K. W. (1974), this J. 12, 477-486.

12. Meinhold, H. \& Wenzel, K. W. (1974), Horm. Metab. Res. 6, 169-170.

13. Bellabarba, D., Peterson, R. \& Sterling, K. (1968), J. Clin. Endocrinol. Metab. 28, 305-307.

14. Ekins, R. P., Newman, G. B., Piyasena, R., Banks, P. \& Slater, J. D. H. (1972), J. Steroid Biochèm. 3, 289-304.

15. Roche, J,, Michel, R., Nunez, J. \& Wolf, W. (1955), C. R. Soc. Biol. 149, 884-887.

16. Stanbury, J. B. \& Morris, M. L. (1957), J. Clin. Endocrinol. Metab. 17, 1324-1331.

17. Chopra, I. J., Sack, J. \& Fisher, D. A. (1975), J. Clin. Invest. $55,1137-1141$.

18. Chopra, I. J. \& Crandall, B. F. (1975), N. Engl. J. Med. 293, $740-743$.

19. Meinhold, H., Wenzel, K. W., Dudenhausen, J. W. \& Saling, E. (1976), Acta Endo crinol. (Copenhagen) Suppl. 204, 28.

Dr. H. Meinhold

Nuklearmedizinische Abteilung Klinikum Steglitz

Freie Universität Berlin

Hindenburgdamm 30

D-1000 Berlin 45 